\title{
Determination of Ascensional Difference in the Lagnaprakarana
}

\author{
Aditya Kolachana*, K Mahesh*, Clemency Montelle** and K Ramasubramanian*
}

(Received 31 January 2018)

\begin{abstract}
The ascensional difference or the cara is a fundamental astronomical concept that is crucial in determining the durations of day and night, which are a function of the observer's latitude and the time of the year. Due to its importance, almost all astronomical texts prescribe a certain procedure for the determination of this element. The text Lagnaprakarana - a hitherto unpublished manuscript attributed to Mādhava, the founder of the Kerala school of astronomy and mathematics-however discusses not one, but a number of techniques for the determination of the cara that are both interesting and innovative. The present paper aims to discuss these techniques.
\end{abstract}

Key words: Arkāgraguṇa, Ascensional difference, Cara, Carajyā, Carāsu, Dyuguṇa, Dyujyā, Earth-sine, Kujyā, Lagnaprakaraṇa, Mādhava, Mahīguṇa

\section{INTRODUCTION}

The ascensional difference (cara henceforth) is an important astronomical element that is involved in a variety of computations related to diurnal problems. It is essentially the difference between the right ascension and the oblique ascension of a body measured in time units. At the time of rising, the cara gives the time interval taken by a body to traverse between the horizon and the six o' clock circle or vice-versa depending upon whether the declination of the body is positive or negative. It is most commonly determined for the Sun because it is this quantity that helps one in finding the time of sunrise and sunset at a given location, for a given time of the year. It is also used in the determination of the rising times of the different zodiacal signs ( $r a \bar{s} s i s)$ at a given latitude.

The Lagnaprakarana ${ }^{1}$ (Treatise for the Computation of the Ascendant) is a work comprised of eight chapters, dedicated to the determination of the ascendant (udayalagna or orient ecliptic point), and discusses numerous techniques for the same. However, as a necessary precursor to determining the ascendant, the text first discusses various methods to obtain the prānakalāntara ${ }^{2}$ as well as the cara. While the procedure for determining the cara is discussed in other astronomical works, no text treats it and related phenomena as thoroughly and comprehensively as the Lagnaprakarana. To demonstrate this, in this paper we excerpt verses from the first chapter of this text which deal with

\footnotetext{
*Cell for Indian Science and Technology in Sanskrit, Indian Institute of Technology Bombay, Powai, Mumbai - 400076; Email: aditya.kolachana@gmail.com

${ }^{* *}$ School of Mathematics and Statistics, University of Canterbury, Christchurch, New Zealand

${ }^{1}$ The authors obtained two manuscripts of the Lagnaprakarana from the Prof. K. V. Sarma Research Foundation, Chennai.

${ }^{2}$ The prānakalāntara (lit. difference between kalās and prānas) is the difference between the longitude and corresponding right ascension of a body.
} 
five different ways to compute the cara (verses 1824), and explain the technical content of the verses along with their rationale.

\section{DETERMINATION OF CARA IN THE LAGNAPRAKARANA}

The Lagnaprakarana presents five different methods for obtaining the cara of the Sun at any latitude, and also discusses how to apply this quantity depending upon the position of the Sun and the time of the day. The first method below is the standard approach to determining the cara given in a number of Indian astronomical texts, while the subsequent methods appear to be unique. ${ }^{3}$

In the following discussion, we employ the symbols $\lambda, \alpha$, and $\delta$ to denote the longitude, right ascension, and declination of the Sun respectively. The symbols $\phi$ and $\epsilon$ are employed to denote the latitude of the observer and the obliquity of the ecliptic respectively. The radius of the diurnal circle, which measures $R \cos \delta$, is generally referred to by the word dyujya . However, in the following verses, the author employs the term dyuguna more frequently.

\section{METHOD 1}

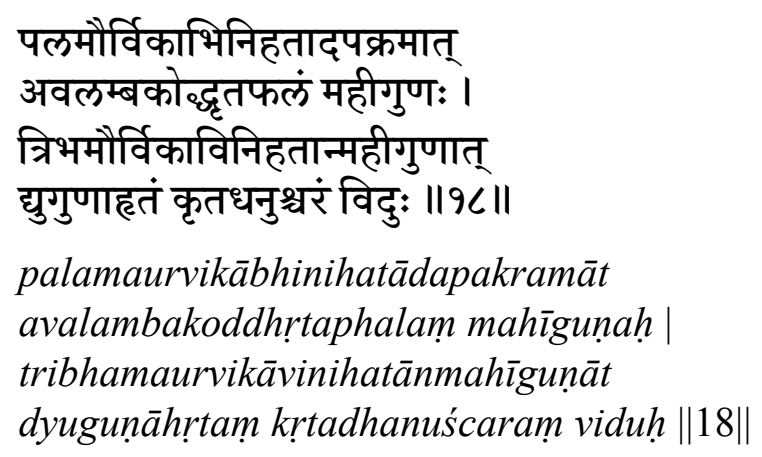

The quotient obtained from dividing the product [of the Rsine] of the declination (apakrama) and the Rsine of the latitude (palamaurvikā) by the Rcosine of the latitude (avalambaka) is the earth-sine (mahīguna). They (i.e. scholars) know [the result] from the radius (tribhamaurvika $)$ multiplied earth-sine divided by the day-radius (dyuguna) converted to an arc to be the ascensional difference (cara).

The above verse composed in the mañjubhāsiṇī metre gives the relations to determine (i) the earthsine (mahiguna), and (ii) the ascensional difference (cara). The given relations can be expressed as follows:

$$
\begin{aligned}
\text { mahīguna } & =\frac{\text { apakramajya } \times \text { palamaurvik } \bar{a}}{\text { avalambakajy } \bar{a}} \\
\text { or, } \quad R \sin M & =\frac{R \sin \delta \times R \sin \phi}{R \cos \phi}
\end{aligned}
$$

and,

$$
\text { cara }=\text { dhanus }\left(\frac{\text { mahīguna } \times \text { tribhamaurvik } \bar{a}}{\text { dyuguṇa }}\right)
$$

or,

$$
\Delta \alpha=R \sin ^{-1}\left(\frac{R \sin M \times R}{R \cos \delta}\right) .
$$

Using (1) in (2), we have

$$
\Delta \alpha=R \sin ^{-1}\left(\frac{R \sin \phi \times R \sin \delta \times R}{R \cos \phi \times R \cos \delta}\right) .
$$

To derive the cara, we refer to Fig. 1, where the Sun has northern declination and therefore rises earlier for an observer in the northern hemisphere compared to an equatorial observer. The measure of this time difference, i.e. cara, is given by the great circle arc $F E$, which corresponds to time taken by the Sun to reach the six o'clock circle (point $Y$ ) after sunrise (point $X$ ). ${ }^{4}$ The relation for the cara given in the verse can be derived from spherical triangle $P Z X$, where $Z X$ is the vertical through $X$. In this triangle, we have

$$
\begin{aligned}
\hat{P} & =90+\Delta \alpha, & & P X=90-\delta, \\
Z X & =90, & & P Z=90-\phi .
\end{aligned}
$$

\footnotetext{
${ }^{3}$ In the Kerala school, Nīlakaṇtha Somayājī (Tantrasangraha, pp. 76-80) gives the same formula as Method 1 for calculating the cara. The Ganita-yukti-bhāṣā does not explicitly show how to calculate the cara. However, methods 4 and 5 below are discussed by Putumana Somayājī (Karaṇapaddhati, pp. 252-256).

${ }^{4} P E$ and $P F$ are meridian circles perpendicular to the equator passing through $Y$ and $X$ respectively.
} 


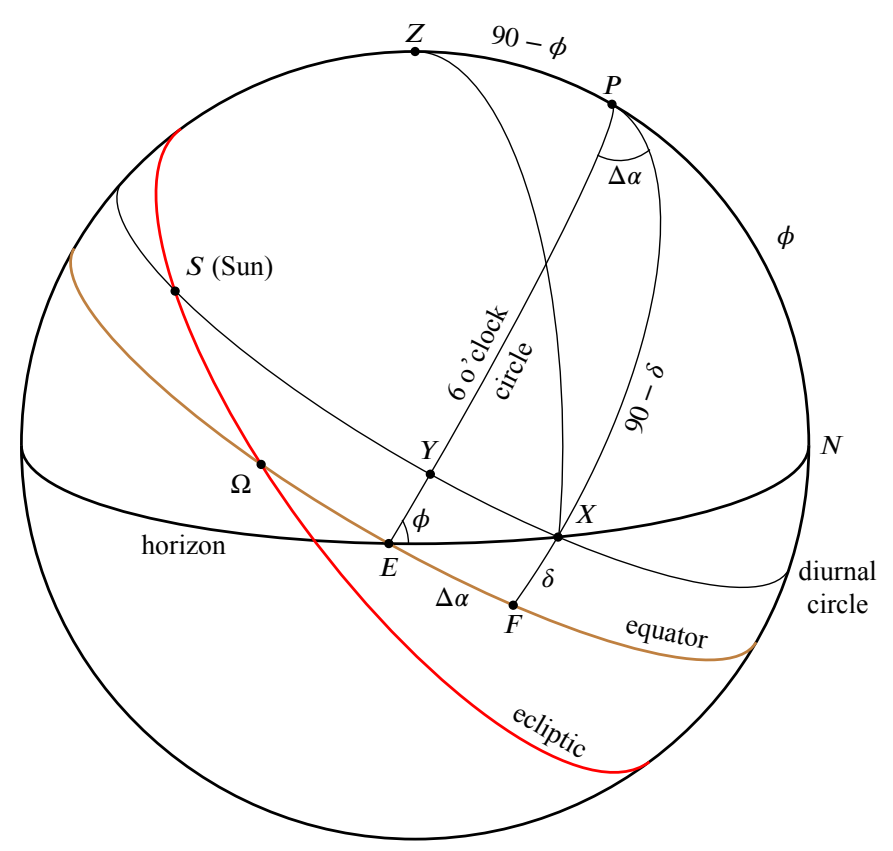

Fig. 1. Determining the earth-sine and the ascensional difference.

Applying the cosine rule of a spherical triangle, we have:

$$
\begin{aligned}
\cos 90= & \cos (90-\phi) \cos (90-\delta) \\
& +\sin (90-\phi) \sin (90-\delta) \cos (90+\Delta \alpha),
\end{aligned}
$$

or,

$$
\Delta \alpha=\sin ^{-1}\left(\frac{\sin \phi \sin \delta}{\cos \phi \cos \delta}\right)
$$

which is the same as (3). ${ }^{5}$

The mahiguna and the Rsine of the cara are the semi-chords of corresponding arcs of the diurnal circle $(X Y)$ and the equator $(F E)$ respectively, and are therefore proportional to their respective radii $R \cos \delta$ and $R$. Therefore, we have the mahìguna

$$
\begin{aligned}
R \sin M & =\frac{R \cos \delta \times R \sin \Delta \alpha}{R} \\
& =\frac{R \sin \delta \times R \sin \phi}{R \cos \phi},
\end{aligned}
$$

which is the same as (1).
It may be noted that the verse prescribes to first determine the mahiguna, and then the cara using this quantity. However, for convenience, here we first derived the cara using spherical trigonometry, and then the mahiguna from it. In contrast to the technique shown here, Indian astronomers typically first derived the mahiguna using planar geometry, and then determined the cara therefrom, using the fact that they are semi-chords of corresponding arcs of the diurnal circle and the equator respectively. The method of deriving the mahīguna using planar geometry is shown in our discussion of Method 2.

\section{METHOD 2}

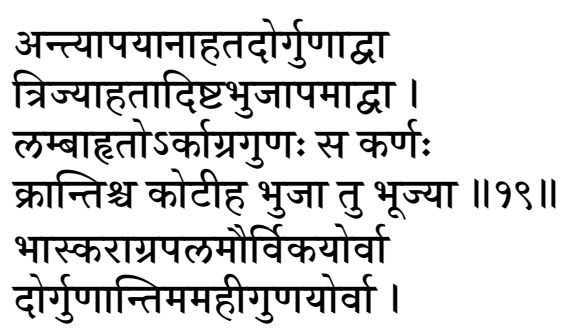

\footnotetext{
${ }^{5}$ The relation for the cara can also be derived from the spherical triangle $E F X$ in Fig. 1 . Here, we have $\hat{E}=90-\phi$, $F E=\Delta \alpha, \hat{F}=90$, and $X F=\delta$. Applying the cotangent four-part formula using these values also gives (3).
} 


\section{घातमत्र विभजेद् दिनमौर्व्या तत्फलं खलु भवेचरजीवा ॥२०॥ \\ antyāpayānāhatadorguṇ̄ $\bar{a} v \bar{a}$ \\ trijyāhatādiștabhujāpamādvā \\ lambāhṛto'rkāgragunah sa karnah \\ krāntiśca koțīha bhujā tu bhüjyā $\|19\|$ \\ bhāskarāgrapalamaurvikayorvā \\ dorguṇāntimamahīgunayorvā | \\ ghātamatra vibhajed dinamaurvyā \\ tatphalam khalu bhaveccarajīv $\bar{a}\|20\|$}

The quotient of either the Rsine (dorguna) [of the Sun's longitude] multiplied by [the Rsine of] the last (maximum) declination (apayāna), or [the Rsine of] the declination (apama) corresponding to the desired longitude multiplied by the radius (trijy $\bar{a}$ ), divided by the Rcosine of the latitude (lamba), is the Rsine of the Sun's amplitude (arkāgraguna). That [Rsine of the Sun's amplitude] is the hypotenuse (karna). [The Rsine of] the declination (krānti) is the upright (kotii) here, and indeed the earth-sine (bhījy $\bar{a})$ is the lateral (bhujā).

Here, one should divide either the product of [the Rsine of] the amplitude of the Sun (bhāskarāgra) and the Rsine of the latitude (palamaurvikā), or of the Rsine (dorguna) [of the Sun's longitude] and the last earth-sine (antimamahiguna), by the day-radius (dinamaurvi $)$. The quotient indeed would be the Rsine of the ascensional difference ( $\operatorname{caraj} \bar{\imath} v \bar{a})$.

The above two verses, composed in the indravajrā and svāgatā metres respectively, together present two expressions for the cara. As these expressions involve the Rsine of the Sun's amplitude $^{6}$ (arkāgraguna) at the time of rising or setting, the verses first present two relations to determine the same, and then describe a right-angled triangle having the mahiguna and the Rsine of the declination as sides, and the arkāgraguna as the hypotenuse.

\section{Expressions for arkāgraguna}

Denoting the Sun's amplitude at the moment of rising or setting as $A^{\prime}$, the two expressions for $\operatorname{ark} \bar{a}$ graguna given in the verse are:

$$
\begin{aligned}
\text { arkāgraguna } & =\frac{\text { dorguṇa } \times \text { antyāpayānajya } \bar{a}}{\text { lambajyā }} \\
\text { i.e., } \quad R \sin A^{\prime} & =\frac{R \sin \lambda \times R \sin \epsilon}{R \cos \phi}
\end{aligned}
$$

and,

$$
\begin{aligned}
\text { arkāgraguna } & =\frac{i \text { ștabhujāpamajy } \bar{a} \times \text { trijy } \bar{a}}{\text { lambajy } \bar{a}} \\
\text { i.e., } \quad R \sin A^{\prime} & =\frac{R \sin \delta \times R}{R \cos \phi} .
\end{aligned}
$$

The above relations can be derived by applying the sine rule to the spherical triangle $E X F$ in Fig. 1. In this triangle, we have

$$
\begin{array}{ll}
E X=A^{\prime}, & X \hat{E} F=90-\phi, \\
X F=\delta, & E \hat{F} X=90 .
\end{array}
$$

Therefore, we have

$$
\begin{aligned}
\frac{\sin A^{\prime}}{\sin 90} & =\frac{\sin \delta}{\sin (90-\phi)} \\
\text { or, } \quad R \sin A^{\prime} & =\frac{R \sin \delta \times R}{R \cos \phi},
\end{aligned}
$$

which is the same as (5). Using the well known relation connecting the longitude and declination of the Sun

$$
\sin \delta=\sin \lambda \sin \epsilon,
$$

the above relation can be written as

$$
R \sin A^{\prime}=\frac{R \sin \lambda \times R \sin \epsilon}{R \cos \phi}
$$

which is the same as (4).

\footnotetext{
${ }^{6}$ Amplitude $\left(A^{\prime}\right)$ refers to the angular distance of separation from the east or west point of the horizon. It is related to the azimuth $(A)$ by the relation $A=90 \pm A^{\prime}$, with the positive sign employed when the arkägraguna is south, and negative sign employed when it is north.
} 


\section{Expression for mahīguna}

Having defined arkāgraguna in the first three quarters of verse 19, the author proceeds to identify what mahīguna or bhüjya is geometrically in the last quarter of the verse. It is said that the right-angled triangle having arkāgraguna as its hypotenuse, has the mahiguna and the Rsine of the declination as its sides. This can be understood from Fig. 2a, which is the same as Fig. 1, but rotated about its axis for ease of visualisation. This figure is depicted in greater detail in Fig. 2b, where $X^{\prime}$ is the projection of the point $X$ on the equatorial plane. The planar right-angled triangle $X O X^{\prime}$ lies in the meridian plane passing through $X$ along which the declination is measured. Therefore, we have $X \hat{O} X^{\prime}=\delta$, and hence

$$
X X^{\prime}=R \sin \delta, \quad O X^{\prime}=R \cos \delta .
$$

The right-angled ${ }^{7}$ triangle $O G X$ lies on the horizon, and $G \hat{O} X=A^{\prime}$. Therefore,

$$
X G=R \sin A^{\prime}, \quad O G=R \cos A^{\prime} .
$$

The right-angled triangle $X G X^{\prime}$ lies in a plane perpendicular to the equator, and parallel to the plane of the prime meridian. Here, we have already determined $X G$ and $X X^{\prime}$ as the Rsines of the amplitude and declination respectively. As in this triangle

$$
\hat{G}=\phi^{\prime}=90-\phi
$$

we have

$$
G X^{\prime}=R \sin A^{\prime} \sin \phi .
$$

This third side $G X^{\prime}$ is nothing but the earth-sine or the mahiguna. This can be understood as follows. Consider the diurnal circle passing through $X$ in Fig. 2a. A perpendicular dropped from $X$ onto the radius of this circle, which is parallel to the line $O E$, will be the earth-sine. $G X^{\prime}$ is the image of this line on the equatorial plane. Therefore,
$X G X^{\prime}$ is the right-angled triangle which the author alludes to in this verse. It may also be noted that upon substituting (5) in the above expression for the mahiguna $\left(G X^{\prime}\right)$, the expression reduces to (1).

\section{Expressions for cara}

In verse 20 , the author gives the following relations to determine the Rsine of the ascensional difference, in terms of the relations described above:

$$
\begin{aligned}
& \text { carajī } \overline{\bar{a}}=\frac{\text { bhāskarāgraguna } \times \text { palamaurvik } \bar{a}}{\text { dinamaurvī }}, \\
& R \sin \Delta \alpha=\frac{R \sin A^{\prime} \times R \sin \phi}{R \cos \delta},
\end{aligned}
$$

and,

$$
\begin{aligned}
& \text { carajī } \bar{a}=\frac{\text { dorguna } \times \text { antimamahīguna }}{\text { dinamaurvi } \bar{l}} \\
& \text { i.e., } \quad R \sin \Delta \alpha=\frac{R \sin \lambda \times R \sin M_{l}}{R \cos \delta} \text {, }
\end{aligned}
$$

where $R \sin M_{l}$ is the last earth-sine, or the earthsine when the declination of the Sun is maximum and equal to the obliquity of the ecliptic. Therefore, substituting $\delta=\epsilon$ in (1), we have

$$
R \sin M_{l}=\frac{R \sin \epsilon \times R \sin \phi}{R \cos \phi} .
$$

The rationale behind (6) can be understood with the help of Fig. 3. This figure is the same as Fig. 2b, only modified to highlight the similar triangles $O G X^{\prime}$ and $O Q F$. From Fig. 2a, we know that $E F$ is the arc corresponding to the ascensional difference, which means that in the planar right-angled triangle $O Q F$ we have the angle $Q \hat{O} F=\Delta \alpha$. As the side $O F=R$ in this triangle, we obtain

$$
F Q=R \sin \Delta \alpha .
$$

We have already shown that $G X^{\prime}=R \sin A^{\prime} \sin \phi$, and $O X^{\prime}=R \cos \delta$. Therefore, considering the similar triangles $O G X^{\prime}$ and $O Q F$, we have

$$
\frac{R \sin \Delta \alpha}{R}=\frac{R \sin A^{\prime} \sin \phi}{R \cos \delta},
$$

\footnotetext{
${ }^{7}$ The triangle does not appear right-angled in the figure due to the difficulty in depicting the three-dimensional celestial sphere on a two-dimensional surface.
} 


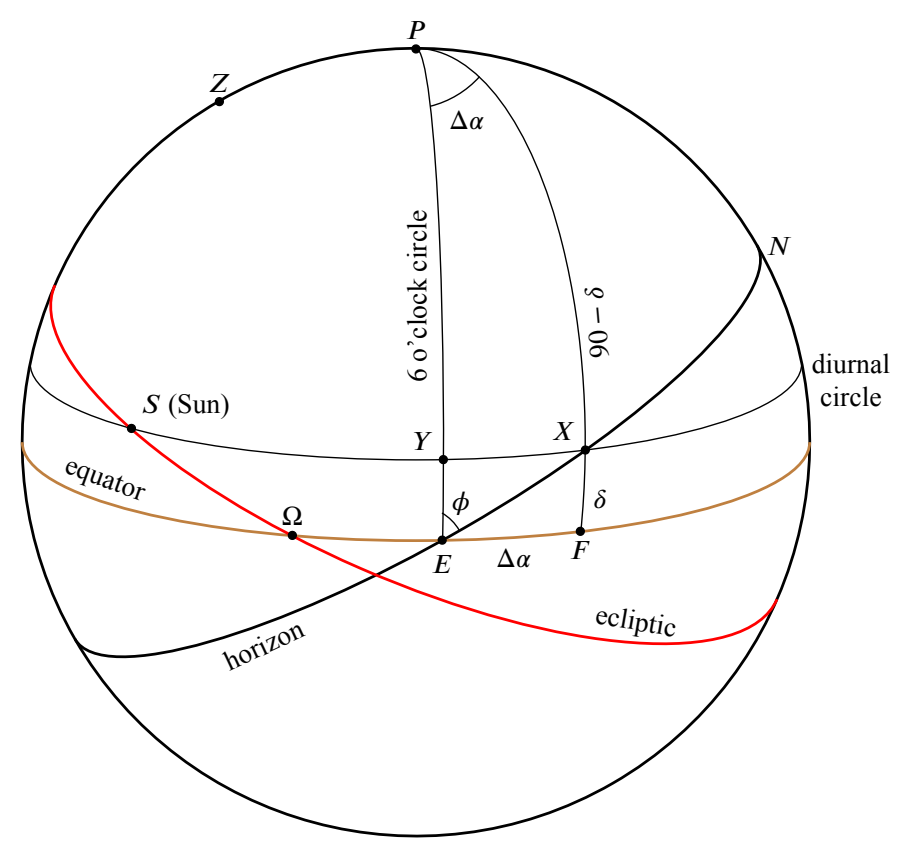

(a) Rotated celestial sphere.

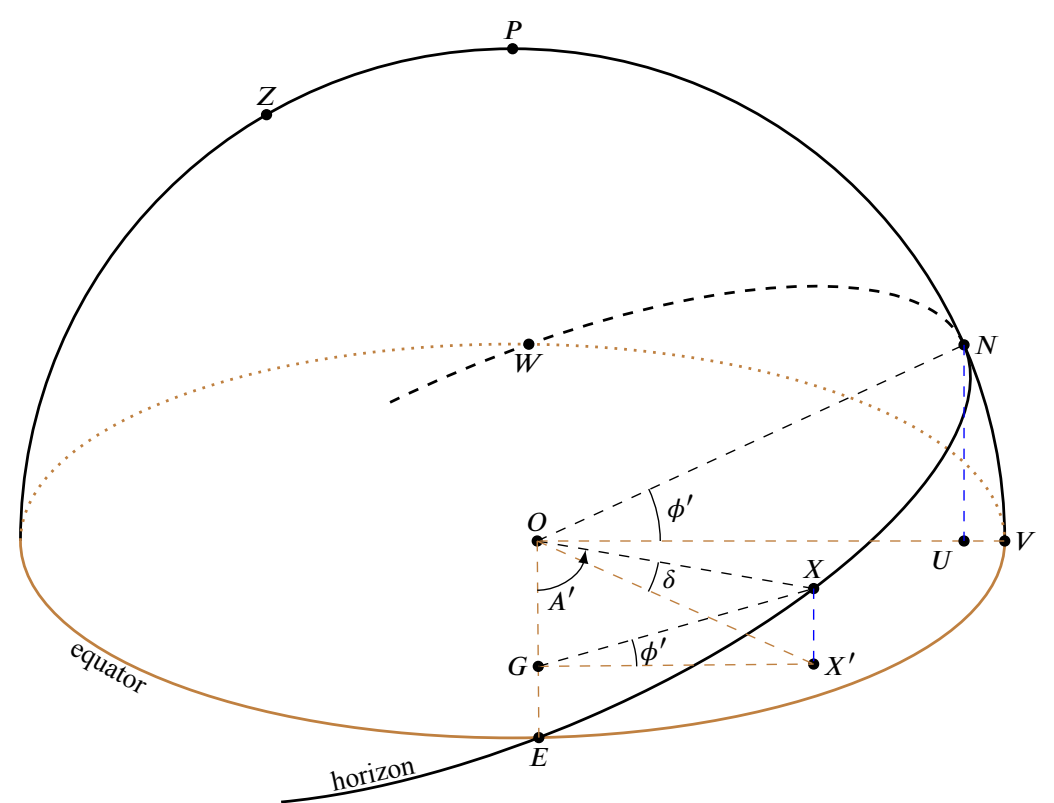

(b) Planar right-angled triangle formed by the amplitude, the declination, and the earth-sine.

Fig. 2. Visualising the triangle which has the amplitude, the declination and the earth-sine as its sides. 
or,

$$
R \sin \Delta \alpha=\frac{R \sin A^{\prime} \times R \sin \phi}{R \cos \delta},
$$

which is the same as (6). Note that (6) can also be validated by simply substituting the relation for $R \sin A^{\prime}$ from (5) into it, upon which the given relation reduces to (3). Similarly, (7) also reduces to (3) upon substituting for $R \sin M_{l}$ using (8) in it.

\section{METHOD 3}

\section{दोर्ज्यावर्गाद् भुजापक्रमकृतिरहितात् मूलमस्यैव कोटि: \\ दोर्ज्याह्यन्त्यद्युजीवा त्रिभगुणविह्ता \\ तद्वर्गादत्र कोटीगुणकृतिसहितात् वापमस्यास्य कोटिः। \\ इष्टापक्रान्तिकोटिश्चरमचरहता मूलमाहुर्द्युजीवाम्}

द्युज्ययाप्ता चरज्या ॥२१॥

dorjyāvargād bhujāpakramakrtirahitāt mūlamasyaiva kotị

dorjyāghnyantyadyujīvā tribhagunavihritā vāpamasyāsya koțị|

tadvargādatra koțīguṇakrtisahitāt mūlamāhurdyujīvām

iṣțāpakrāntikoțiścaramacarahatā dyujyayāptā carajyā $\|21\|$

The square-root taken from-the square of the Rsine (dorjy $\bar{a})$ [of the Sun's longitude] decreased by the square of [the Rsine of] the declination corresponding to the longitude (bhuja pakrama) - is the koti of this [declination] itself. Or, the last day-radius (antyadyujī vā) multiplied by the Rsine (dorjy $\bar{a}$ ) [of the Sun's longitude] and divided by the radius (tribhaguna) is the koti corresponding to this declination (apama). Here, [scholars] state the square root taken from-its (koti) square increased by the square of the Rcosine (kotinguna) [of the Sun's longitude] — to be the day-radius $($ dyujī $v \bar{a})$. The $k o t i$ of the desired declination multiplied by the maximum ascensional difference (caramacara) and divided by the day-radius (dyujy $\bar{a})$ is the Rsine of the ascensional difference (carajya $\bar{a}$ ).

The above verse is composed in the long sragdharā metre, consisting of twenty-one syllables per quarter. The choice of the long metre for this verse stems from the fact that the author gives several relations here. The first two relations are meant for defining a quantity called the koti $i$ Next, he defines a relation for determining the radius of the diurnal circle (dyujī $v \bar{a})$ in terms of koti. This is followed by an expression for the Rsine of the ascensional difference (carajya $)$ in terms of koti $i$ and dyujīva $\bar{a}$. The expressions for koți along with their equivalent in mathematical notation are: ${ }^{8}$

$$
\begin{aligned}
k o t ̦ i & =\sqrt{(\text { dorjy } \bar{a})^{2}-(\text { bhujāpakramajy } \bar{a})^{2}} \\
& =\sqrt{(R \sin \lambda)^{2}-(R \sin \delta)^{2}}
\end{aligned}
$$

or,

$$
\begin{aligned}
\text { koți } & =\frac{\text { dorjy } \bar{a} \times \text { antyadyujī } \bar{a}}{\text { tribhaguna }} \\
& =\frac{R \sin \lambda \times R \cos \epsilon}{R} .
\end{aligned}
$$

The dyujīva and carajy $\bar{a}$ are given as

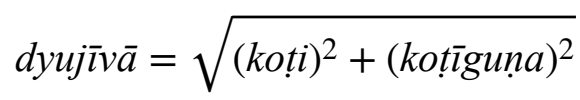

$$
\begin{aligned}
& \text { or, } \quad R \cos \delta=\sqrt{(k o t i)^{2}+(R \cos \lambda)^{2}},
\end{aligned}
$$

and

$$
\begin{aligned}
\text { carajy } \bar{a} & =\frac{k o t ̦ i \times \text { caramacarajy } \bar{a}}{\text { dyujy } \bar{a}} \\
\text { or, } \quad R \sin \Delta \alpha & =\frac{k o t ̦ i \times R \sin \Delta \alpha_{m}}{R \cos \delta},
\end{aligned}
$$

where $\Delta \alpha_{m}$ is the maximum ascensional difference which occurs at the maximum declination of the Sun. Therefore, substituting $\delta=\epsilon$ in (1) and (2), from the two equations we have

$$
R \sin \Delta \alpha_{m}=\frac{R \sin \epsilon \times R \sin \phi}{R \cos \phi} \times \frac{R}{R \cos \epsilon} .
$$

\footnotetext{
${ }^{8}$ The phrase 'koti corresponding to this declination' in the verse is not to be confused with the Rcosine of the declination here. Instead, it is to be taken as a technical term denoting the given mathematical expressions.
} 


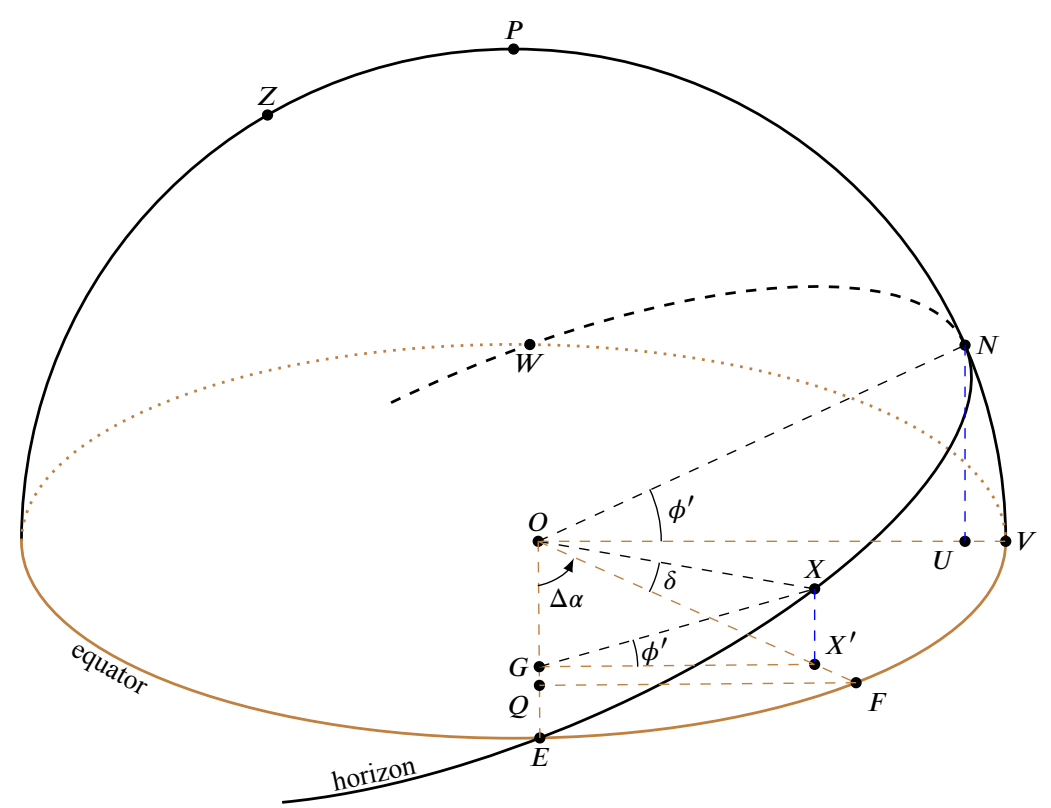

Fig. 3. Determining the relation for the cara.

\section{Rationale for the expressions for koti and $\operatorname{dyuj\overline {\imath }} v \bar{a}$}

We now show that the expression for the koți described in this verse corresponds to the line segment $T S^{\prime}$ shown in Fig. 4, which depicts the celestial sphere from the point of view of the equatorial plane. Here, let $S$ be the Sun, having longitude $\lambda$ and declination $\delta$. In the right-angled triangle $S T S^{\prime}$, we have the side $S S^{\prime}=R \sin \delta$, and the hypotenuse $T S=R \sin \lambda$. As $S \hat{T} S^{\prime}$ is nothing but the angle between the equator and the ecliptic, we have $S \hat{T} S^{\prime}=\epsilon$. Therefore,

$$
T S^{\prime}=R \sin \lambda \cos \epsilon .
$$

This is equivalent to the expression for koti given in (10). In the right-angled triangle $S T S^{\prime}$, we also have

$$
T S^{\prime 2}=T S^{2}-S S^{\prime 2}
$$

Noting $T S^{\prime}=k o t i$, and substituting the values of the other two sides of the triangle in this expression yields (9).

Similarly, (11) can be easily derived by considering the right-angled triangle $O T S^{\prime}$ in the same figure. In this triangle, we have the hypotenuse $O S^{\prime}=R \cos \delta$, and the sides $O T=R \cos \lambda$, and $T S^{\prime}=$ koti . Since $O S^{\prime 2}=T S^{\prime 2}+O T^{2}$, we obtain (11).

\section{Rationale for the expression for the carajy $\bar{a}$}

The given expression for the carajya or the Rsine of the ascensional difference can be understood with the help of Fig. 3 as well as Fig. 4. In Fig. 3, noting that $O N=R$, and that $G X^{\prime}$ is the mahiguna, ${ }^{9}$ from similar triangles $X G X^{\prime}$ and $N O U$, we have

$$
R \sin \delta=\text { mahīguna } \times \frac{R \sin \phi^{\prime}}{R \cos \phi^{\prime}} .
$$

In Fig. 4, noting that $O S_{1}=R$ and $T S^{\prime}$ is the koti, from similar triangles $S T S^{\prime}$ and $S_{1} O D$, we have

$$
R \sin \delta=k o t i \times \frac{R \sin \epsilon}{R \cos \epsilon} .
$$

\footnotetext{
${ }^{9}$ See Method 2.
} 


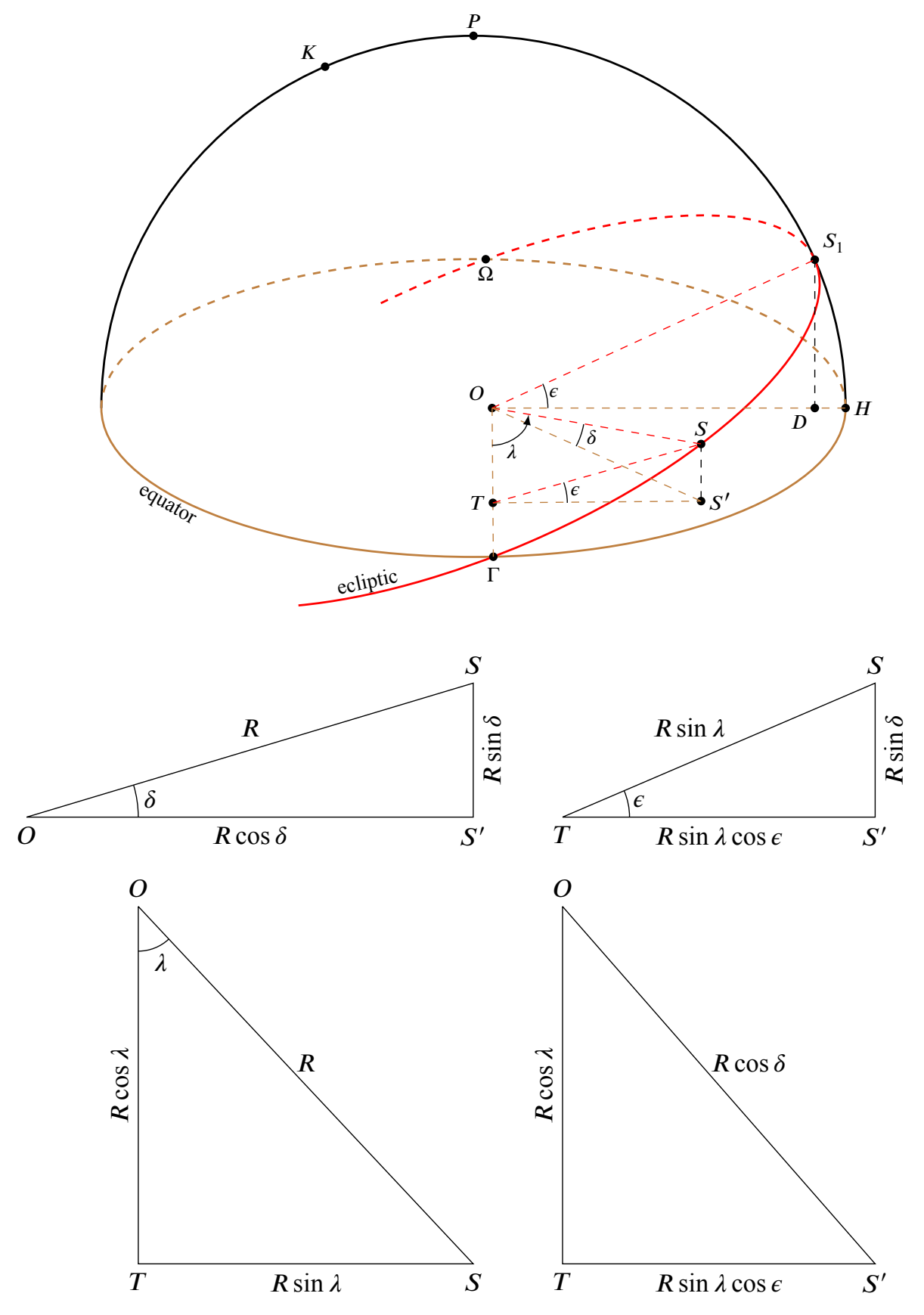

Fig. 4. Understanding the term koti. 
Equating the above two expressions, noting $\phi^{\prime}=$ The cara is then given in terms of the $k \bar{a} l a j \bar{\imath} v \bar{a}$ as: $90-\phi$, and rearranging, we have the mahiguna

$$
\begin{aligned}
R \sin M & =\frac{k o t i \times R \sin \epsilon \times R \sin \phi}{R \cos \epsilon \times R \cos \phi} \\
& =\frac{k o t i \times R \sin \Delta \alpha_{m}}{R} . \quad[\text { using (13)] }
\end{aligned}
$$

Now, multiplying both sides by $\frac{R}{R \cos \delta}$, and using (2), we have

$$
R \sin \Delta \alpha=\frac{k o t i \times R \sin \Delta \alpha_{m}}{R \cos \delta}
$$

which is the required expression (12).

\section{METHOD 4}

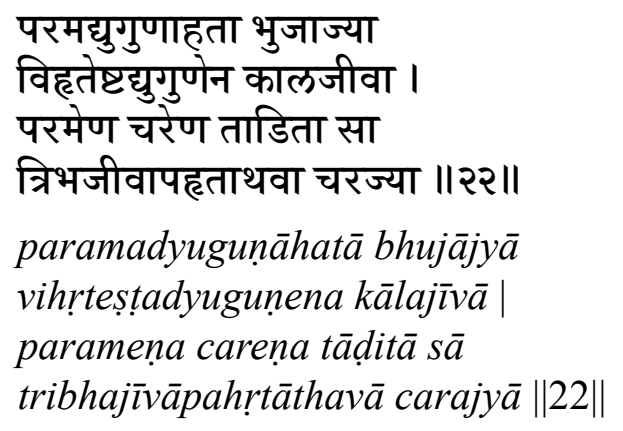

Or, the Rsine (bhujājyā) [of the Sun's longitude] multiplied by the extreme (last) dayradius (paramadyuguna) and divided by the desired day-radius (iștadyuguna) is the Rsine of the right ascension $(k \bar{a} l a j \bar{\imath} v \bar{a})$. That $(k \bar{a} l a-$ $j \bar{\imath} v \bar{a}$ ) multiplied by [the Rsine of] the maximum ascensional difference (parama cara), and divided by the radius (tribhaji $v \bar{a})$, is the Rsine of the ascensional difference ( $\operatorname{carajy} \bar{a})$.

The above verse composed in the mâlabhärin̄ metre prescribes the formula for obtaining cara in terms of the kālajī $v \bar{a}$ or the Rsine of the Sun's right ascension. For this purpose, the verse first gives an expression for the kālajīva as follows:

$$
\begin{aligned}
\text { kālajī } \bar{a} & =\frac{\text { bhujājyā } \times \text { paramadyuguna }}{\text { ișțadyuguna }} \\
\text { or, } \quad R \sin \alpha & =\frac{R \sin \lambda \times R \cos \epsilon}{R \cos \delta} .
\end{aligned}
$$

$$
\begin{aligned}
\text { carajy } \bar{a} & =\frac{k \bar{a} l a j \bar{i} v \bar{a} \times \text { paramacarajy } \bar{a}}{\text { tribhajī } \bar{\imath} \bar{a}} \\
\text { or, } \quad R \sin \Delta \alpha & =\frac{R \sin \alpha \times R \sin \Delta \alpha_{m}}{R} .
\end{aligned}
$$

The expression for the right ascension given by (14) can be understood using Fig. 5. This figure is the same as Fig. 4, only modified to highlight the similar triangles $O T S^{\prime}$ and $O C B$. Here, the arc $\Gamma B$ represents the right ascension of the Sun, and therefore $B \hat{O} C=\alpha$. As $O B=R$, we have the semi-chord

$$
C B=R \sin \alpha .
$$

We also already know that ${ }^{10}$

$$
T S^{\prime}=R \sin \lambda \cos \epsilon, \quad \text { and } \quad O S^{\prime}=R \cos \delta .
$$

Now, from similar triangles $O T S^{\prime}$ and $O C B$, we have

$$
\begin{aligned}
\frac{R \sin \alpha}{R} & =\frac{R \sin \lambda \cos \epsilon}{R \cos \delta} \\
\text { or, } \quad R \sin \alpha & =\frac{R \sin \lambda \times R \cos \epsilon}{R \cos \delta},
\end{aligned}
$$

which is the same (14).

From (10) and (14), we have

$$
\frac{k o t i}{R \cos \delta}=\frac{R \sin \alpha}{R} .
$$

One can easily see that substituting the above expression in (12) yields (15).

\section{METHOD 5}

त्रिज्याक्षघातलम्बांशागुणिता क्रान्तिमौर्विका । द्युज्याप्ता चरजीवा स्यात् तचापं हि चरासवः ॥२३॥

trijyākṣaghātalambāmśs -

gunitā krāntimaurvikā |

dyujyāptā carajī vā syāt

taccāpam hi carāsavaḥ $\|23\|$

\footnotetext{
${ }^{10}$ See Method 3.
} 


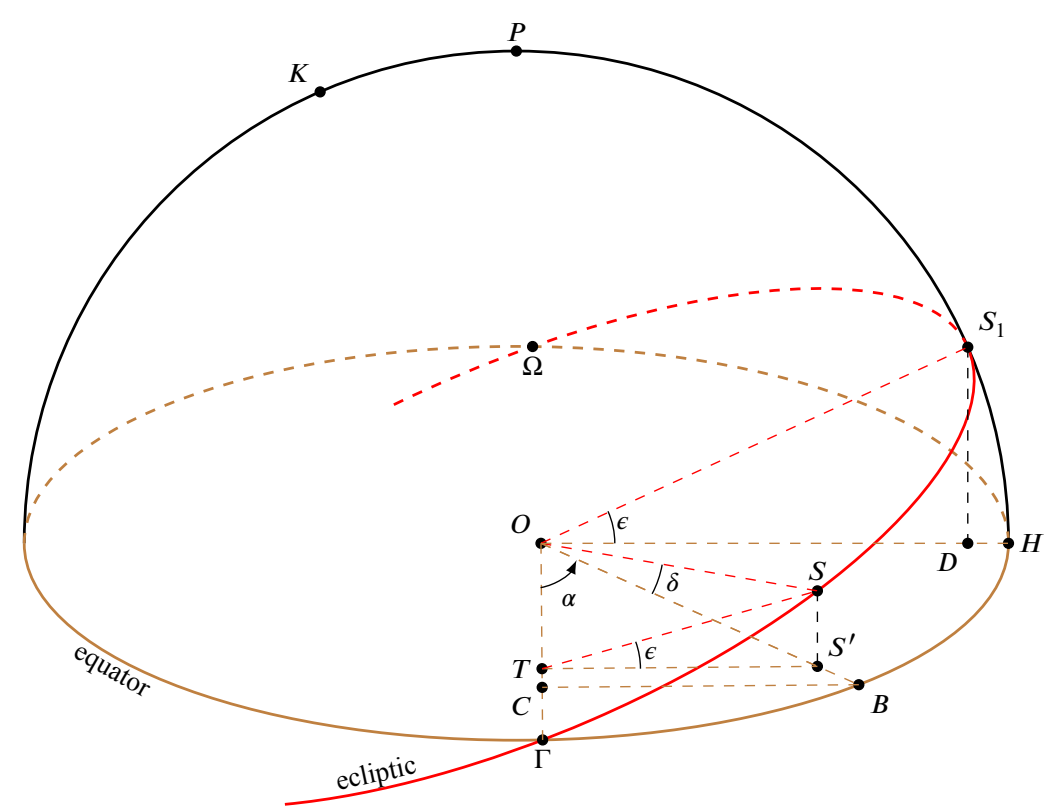

Fig. 5. Derivation of $k \bar{a} l a j \bar{\imath} v \bar{a}$ or right ascension.

The Rsine of the declination (krāntimaurvikā) multiplied by one-lambath ${ }^{11}$ part of the product of the radius (trijy $\bar{a}$ ) and [the Rsine of] the latitude $(a k s a)$ and divided by the day-radius (dyujy $\bar{a}$ ) would be the Rsine of the ascensional difference $(\operatorname{caraji} \bar{i} \bar{a})$. Indeed, its arc would be the ascensional difference in arc-minutes (carāsavaḥ).

The above verse in the anuștubh metre gives the following relations:

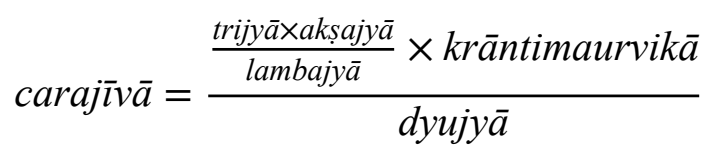

$$
\begin{aligned}
& \text { or, } \quad R \sin \Delta \alpha=\frac{\frac{R \times R \sin \phi}{R \cos \phi} \times R \sin \delta}{R \cos \delta},
\end{aligned}
$$

and,

$$
\begin{aligned}
\text { carāsu } & =c \bar{a} p a(\operatorname{carajī} v \bar{a}) \\
\text { or, } \quad \Delta \alpha & =R \sin ^{-1}(R \sin \Delta \alpha) .
\end{aligned}
$$

The above expressions are a restatement of (2), upon substituting for the mahiguna from (1).

\section{APPLICATION OF THE ASCENSIONAL DIFFERENCE}

प्रातश्चरं वणिगजादिवशाद्धनर्णम् अस्ते ऽन्यथा न तदहर्निशायोस्तु मध्ये। कार्यं त्रिपच्चमलवादिषु चानुपातात् नैवानुपातविधिरस्य घटीप्रसारे ॥२४॥

prātaścaram vaṇigajādivaśāddhanarnam aste'nyathā na tadaharniśayostu madhye | kāryam tripañcamalavādiṣu cānupātāt naivānupātavidhirasya ghațīprasāre ||24\|

At sunrise, the ascensional difference is positive or negative depending on [the Sun's position with regard to] Libra or Aries. While setting, it is otherwise. That should not be applied during midst of the day and night. And in case of third, fifth etc. portions [of the day, the cara] should be calculated [afresh] successively. The rule of proportion for this (cara) will not be applicable in [setting] the motion of the clock (ghațīprasāra).

\footnotetext{
${ }^{11}$ The term lamba refers to the Rcosine of the latitude. The compound word लम्बांशा is to be understood here as लम्बेन विभज्याप्तः अंशाः। This is an unusual way to express division by a variable.
} 
This verse composed in the vasantatilak $\bar{a}$ me- mine $t_{\phi}$ is summarised in Table 1. tre prescribes rules for the application of the cara depending upon the time of the day, and the Sun's position on the ecliptic for an observer in the northern hemisphere. The verse also briefly comments on the nature of the cara function.

\subsection{Application of cara at sunrise and sunset}

When the Sun is in the northern hemisphere (i.e. its longitude is in the range of $0^{\circ}$ to $180^{\circ}$, referred to as ajādi or 'beginning with Aries' in the verse), the cara is to be subtracted in the morning, and added in the evening to obtain the time of the local sunrise and sunset respectively. This is because, during this period, the Sun rises earlier and sets later than at the equator, where sunrise and sunset occur at six o'clock throughout the year.

Fig. 6a depicts the cara at the time of sunrise when the Sun has northern declination. Here, it can be seen that the Sun reaches the horizon at point $X$ before crossing the six o'clock circle at point $Y$. Therefore, the Sun rises before 6 a.m. The cara gives the magnitude of this difference and needs to be subtracted from six o'clock to determine the local time of sunrise. Fig. $6 \mathrm{~b}$ depicts the cara at the time of sunset when the Sun has northern declination. Here, it can be seen that the Sun first reaches the six o'clock circle at point $Y$, before it sets at point $X$. Therefore, the Sun sets after 6 p.m., and the cara needs to be added to determine the time of local sunset.

On the other hand, when the Sun is in the southern hemisphere, the cara is to be applied positively in the morning, and negatively in the evening to obtain the time of local sunrise and sunset respectively. This is because, during this period, the Sun rises later and sets earlier than for observers at the equator, and the duration of the day is shorter for observers in the northern hemisphere. Figures $6 \mathrm{c}$ and $6 \mathrm{~d}$ depict this situation. If $t_{e}$ is the time of sunrise or sunset at the equator, and $t_{\phi}$ is the time of sunrise or sunset at a desired latitude $(\phi)$, then application of cara in different situations to deter-

\subsection{Application of cara at noon and midnight}

It is clearly stated in the verse that the correction due to ascensional difference is zero at the midst of the day and the night. In other words, the magnitude of the cara at the prime meridian is zero at mid-noon and mid-night when the Sun reaches the prime meridian either during the day or the night, irrespective of the latitude of the observer. This is another way of stating that the Sun reaches the prime meridian at the same instant for all observers on a given longitude.

After discussing the application of cara at sunrise, sunset, noon, and midnight, the author makes noteworthy remarks about the very nature of the cara function itself, not usually found in other astronomical works.

\subsection{The nature of the cara function}

In the latter half of the verse, the author makes the following remarks regarding the nature of the cara function from a mathematical viewpoint:

(i) the cara has to be computed successively during every third part, or fifth part etc. of the day, and

(ii) the variation in cara cannot be taken to be proportional to the change in time for setting the clock.

It seems to us that the intent of the author here is to caution against assuming a linear variation in cara from sunrise to noon, and also from noon to sunset. This prescription to determine cara successively at various intervals during the day, and not to apply the method of proportion while setting the clock is quite interesting and gives us a clue to the fact that the day-irrespective of its duration - was divided into a fixed number of units, for certain purposes. Clearly, the duration of each such unit would vary over the course of the year along with 


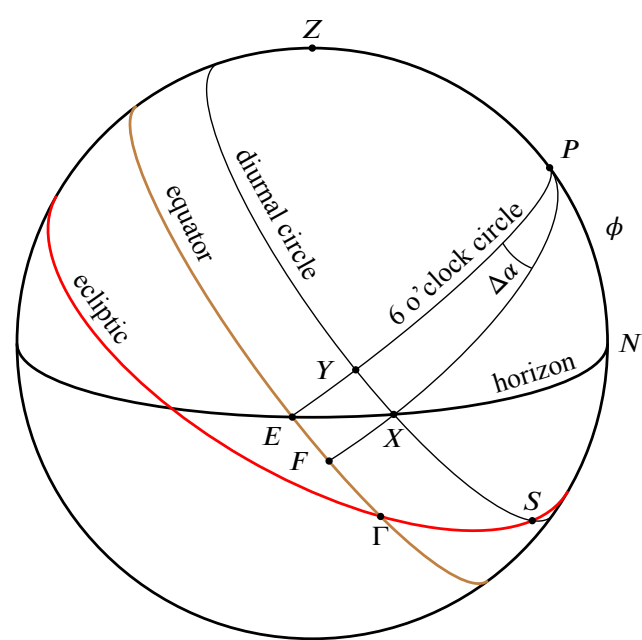

(a)

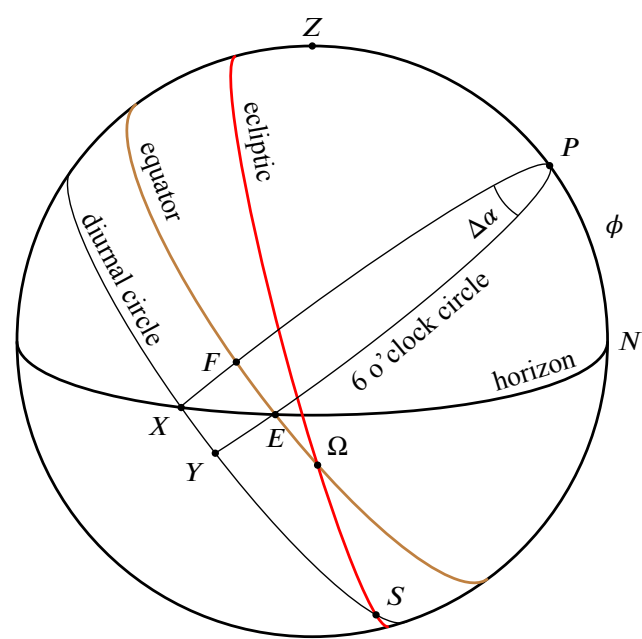

(c)

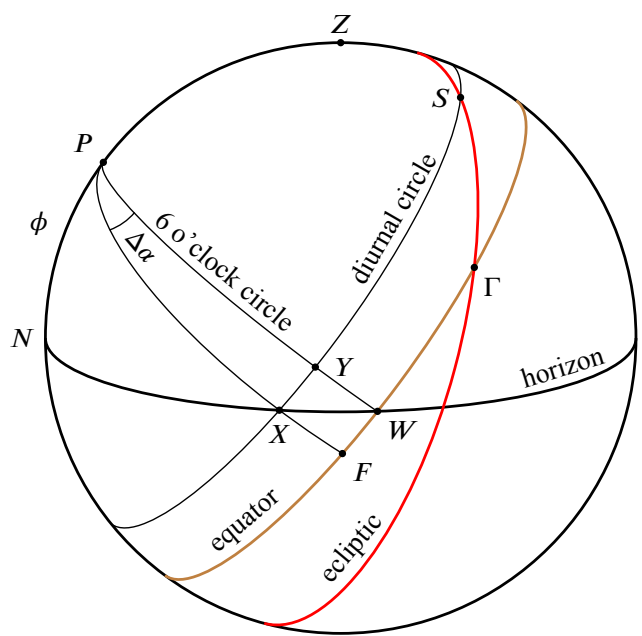

(b)

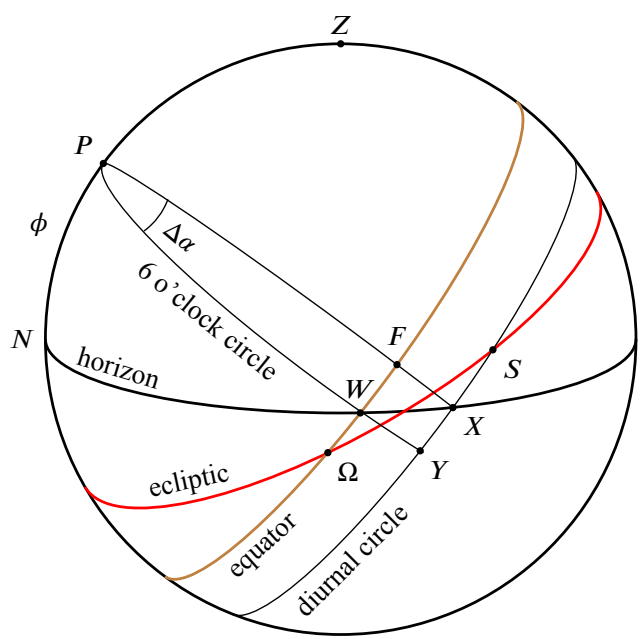

(d)

Fig. 6. Application of cara at sunrise and sunset for an observer in the northern hemisphere: (a) and (b) Sun having northern declination, (c) and (d) Sun having southern declination.

Table 1. Application of cara in determining the time of local sunrise and sunset for an observer in the northern hemisphere.

\begin{tabular}{ccc}
\hline Sun's declination & Sunrise & Sunset \\
\hline North & $t_{\phi}=t_{e}-\Delta \alpha$ & $t_{\phi}=t_{e}+\Delta \alpha$ \\
South & $t_{\phi}=t_{e}+\Delta \alpha$ & $t_{\phi}=t_{e}-\Delta \alpha$ \\
\hline
\end{tabular}


day length, as indicated by the following verse of Srīpati: ${ }^{12}$

दिनस्य यः पज्चदरो विभागो
रात्रेस्तथा तद्धि मुहूर्तमानम् ।
dinasya yah pañcadaśo vibhāgo
rātrestathä taddhi muhūrtamānam
Muhürta is that [span of time] which is [equal
to] one fifteenth of a day; and also of the night
similarly.

The verse clearly states a muhürta is equal to onefifteenth of a day, indicating that it is not a fixed time unit, but rather varies with the length of the day (and night) over the course of the year.

Now, in the Lagnaprakarana, the author seems to be indicating that the variation in the cara is to be considered even while measuring time during a day, and that this variation cannot be considered to be proportional to the change in time. In any case, it is quite interesting and noteworthy that the author presents such discussions in the context of application of cara. Obviously, building any such clock which takes into account the non-linear variation of cara would be quite complicated. However, it may be noted that in the calculation of the śanku and the drggati in verses 53-56 of the Lagnaprakarana, the author makes use of the cara which is determined using the declination of the Sun (or an ecliptic point ninety degrees behind it) at a desired instant, rather than at sunrise. Therefore, it is clear that the author definitely had a theoretical use for this quantity, whether or not it had any practical application.

\section{CONCLUSION}

Of the various approaches for determining the cara described in the article, the first method will be familiar to most students of Indian astronomy as that which is discussed in standard astronomical texts like the Siddhāntaśiromani. ${ }^{13}$ The subsequent methods are more interesting and involve determining the cara using parameters like the amplitude of the Sun, the maximum earth-sine, the maximum cara, and so on. Methods 2, 3 and 4 in particular showcase a great dexterity and artistry in conceiving of various planar triangles and projections that lead to a variety of formulae and approaches for arriving at the same result. This indeed reveals a strong grasp of mathematical and astronomical concepts.

While method 5 is a modification of method 1, the subsequent discussion on the application of the cara at different times of the year and during different times of the day is important to help students understand the practical application of an otherwise abstract astronomical concept. The author deserves praise for succinctly conveying several mathematical results in a single verse, and in one particular case, all the information contained in $\mathrm{Ta}-$ ble 1 in less than two quarters of a verse.

The variety of approaches presented here to compute the same physical quantity suggests that the purpose of this work was more than just providing users with a way to compute the cara. It was fundamentally about showcasing the number of ways in which the same phenomenon could be described mathematically, and thus demonstrating a certain mathematical ingenuity and facility. Taken in conjunction with the thorough exposition on the pränakaläntara in this same text, ${ }^{14}$ the above discussion certainly reveals a deftness and robustness of approach towards solving problems which are signs of a pure mathematician. Being privy to subsequent discussions in the Lagnaprakarana, we are confident that our future investigations will only further strengthen this claim.

\footnotetext{
${ }^{12}$ The given verse is attributed to Śrīpati by the commentator of the Muhūrtakalpadruma. See Vițthala Dīkșita (Muhūrtakalpadruma, p. 43). The exact origin is unclear. Similar verses are found in many muhūrta texts.

${ }^{13}$ See Bhāskarācārya (Siddhāntaśiromaṇi, p. 114).

${ }^{14}$ See Kolachana, Mahesh, and Ramasubramanian ("Mādhava's multi-pronged approach for obtaining the prānakalāntara").
} 


\section{ACKNOWLEDGEMENTS}

The authors would like to place on record their sincere gratitude to MHRD for the generous support extended to them to carry out research activities on Indian science and technology by way of initiating the Science and Heritage Initiative (SandHI) at IIT Bombay. They also would like to pay their obeisance to the late Prof. K. V. Sarma, who saved the Lagnaprakarana for future generations by painstakingly copying the crumbling manuscripts of the text. Finally, they also would like to acknowledge the K. V. Sarma Research Foundation, Chennai, for sharing the manuscripts, which enabled them to study this interesting and important work.

\section{BIBLIOGRAPHY}

Āryabhața. Arryabhațīya. Ed., trans., and comm. by K. S. Shukla and K. V. Sarma. 3 vols. New Delhi: Indian National Science Academy, 1976.

Bhāskarācārya. Siddhāntaśiromaṇi. With a comment. by Satyadeva Sharma. Varanasi: Chaukhamba Surabharati Prakashan, 2007.

Brahmagupta. Brāhmasphuțasiddhānta. Ed. and comm. by Sudhakara Dvivedi. Reprint from The Pandit. Varanasi (formerly Benares): Printed at the Medical Hall Press, 1902.

Gangooly, Phanindralal, ed. Sūryasiddhānta. Trans. and comm. by Ebenezer Burgess. Delhi: Motilal Banarasidass Publishers Private Limited, 2000.
Jñānarāja. Siddhāntasundara. Trans. and comm. by Toke Lindegaard Knudsen. Baltimore: John Hopkins University Press, 2014.

Jyeșthadeva. Gaṇita-yukti-bhāṣāa. Ed. and trans. by K. V. Sarma. With a comment. by K. Ramasubramanian, M. D. Srinivas, and M. S. Sriram. 2 vols. Culture and History of Mathematics 4. New Delhi: Hindustan Book Agency, 2008 .

Kolachana, Aditya, K. Mahesh, and K. Ramasubramanian. "Mādhava's multi-pronged approach for obtaining the prānakalāntara". In: Indian Journal of History of Science 53.1 (2018), pp. 1-15.

Lalla. Sisyadhīvrddhidatantra. Ed., trans., and comm. by Bina Chatterjee. 2 vols. New Delhi: Indian National Science Academy, 1981.

Mādhava. "Lagnaprakaraṇa". Manuscript 414 B, ff. 5384. Kerala University Oriental Research Institute and Manuscripts Library, Thiruvananthapuram.

- "Lagnaprakarana". KVS Manuscript No. 37a. Prof. K. V. Sarma Research Foundation, Chennai.

- “Lagnaprakarana”. KVS Manuscript No. 37b. Prof. K. V. Sarma Research Foundation, Chennai.

Nīlakanththa Somayājī. Tantrasañgraha. Trans. and comm. by K. Ramasubramanian and M. S. Sriram. Culture and History of Mathematics 6. New Delhi: Hindustan Book Agency, 2011.

Putumana Somayājī. Karañapaddhati. Trans. and comm. by Venkateswara Pai et al. Culture and History of Mathematics 9. New Delhi: Hindustan Book Agency, 2017.

Vateśvara. Vațeśvarasiddhānta. Ed., trans., and comm. by Kripa Shankar Shukla. 2 vols. New Delhi: Indian National Science Academy, 1986.

Viț̣hala Dīkșita. Muhūrtakalpadruma. Ed. by Sureshchandra Mishra. New Delhi: Ranjan Publications, 2005. 